\title{
The Importance of Biosemiotics for Morphology
}

\author{
Joachim Schult ${ }^{1} \cdot$ Onno Preik ${ }^{2} \cdot$ Stefan Kirschner ${ }^{1}$
}

Received: 15 May 2020 / Accepted: 17 November 2020 / Published online: 15 December 2020

(C) The Author(s) 2020

\begin{abstract}
Morphology and its relevance for systematics is a promising field for the application of biosemiotic principles in scientific practice. Genital coupling in spiders involves very complex interactions between the male and female genital structures. As exemplified by two spider species, Nephila clavipes and Nephila pilipes ssp. fenestrata, from a biosemiotic point of view the microstructures of the male bulb's embolus and the corresponding female epigynal and vulval parts form the morphological zone of an intraspecific communication and signinterpreting process that is one of the prerequisites for sperm transfer. Hence these morphological elements are of high taxonomic value, as they play an essential role in mating and fertilization and consequently in establishing and preserving a reproductive community. Morphology clearly benefits from a biosemiotic approach, as biosemiotics helps to sort out species-specific morphological characters and to avoid problematic typological interpretations.
\end{abstract}

Keywords Biosemiotics $\cdot$ Character interpretation $\cdot$ Morphological characters $\cdot$ Nephila clavipes $\cdot$ Nephila pilipes ssp. fenestrata $\cdot$ Recognition window $\cdot$ Reductionism $\cdot$ Species problem

Joachim Schult

joachim.schult@uni-hamburg.de

Onno Preik

onno.a.preik@studium.uni-hamburg

Stefan Kirschner

stefan.kirschner@uni-hamburg.de

1 Department of Biology, History of Science Research Unit, University of Hamburg, Bundesstr. 55, 20146 Hamburg, Germany

2 Department of Biology, Behavioural Biology Research Unit, University of Hamburg, Martin-Luther-King Platz 3, 20146 Hamburg, Germany 


\section{Introduction}

In his preface to Barbieri's (2003) work, "The organic codes", the evolutionary biologist Ghiselin (2003: ix) pointed out:

"Most scientific publications deal with problems that can be explained in a straightforward manner and with solutions that can be evaluated as a matter of routine. But scientific progress often occurs when somebody tries to reformulate the problem, or to suggest a different kind of solution. When that happens, it may be necessary to dwell as much upon the questions as upon the answers, and to show how a novel approach might give further significant results." (italics ours)

Taking this citation as an inspiration, the purpose of our paper is to show by an example from spider taxonomy that biosemiotics as a novel approach has the potential to overcome widespread and straightforward, but insufficient explanations concerning the function of specific morphological structures in spider genital organs. In this way biosemiotics simultaneously contributes to restrengthening morphology, which has experienced a severe decline starting in the twentieth century.

Biosemiotics, which studies the production and interpretation of signs and codes in living systems (Favareau 2010; Kull 2016), is essentially derived from Peircean semiotics, but also from more zoologically oriented roots such as Jakob von Uexküll's concept of Umwelt (Kull 1999), then general system theory, later cybernetics, information theory etc. Based on these origins biosemiotics is an interdisciplinary attempt to capture the diversity and complexity of living systems. The central notion of biosemiotics is "sign". A sign represents an object and is interpreted by a sign receiver. The object can be abstract, i.e. without physical referents, or concrete. Drawing on Peircean semiotics Laubichler (1999) states that whatever biology works on, be it measurement data, molecular or morphological structures, it is representamina or sign vehicles, not objects. Taking into consideration the manifold interactions of life as signs biosemiotics is able to integrate a series of biological phenomena that previously were unrelated and not compatible with each other. The basic idea is that biology is based on communication processes on all levels, from the molecular level to ecosystems (Gérard 2014), so that life processes can be viewed as sign-mediated interactions. Life phenomena are, in all aspects, natural semiotic systems. Permeating the entire biology, the sign is a useful key and a practically relevant access to the understanding of life. The connection between biology and semiotics is characterized by Pattee (1995) as follows: "Communication is the essence of life." A particularly lucid and catchy explanation of what biosemiotics is about has been given by Kull (2016: 61):

"A semiotic approach in biology means the study of the organisms' own approach, the study of distinctions that they make, what they recognise, what they intend, what they know, in a broad sense."

At present, however, there is only a slowly spreading tendency of incorporating biosemiotic principles and approaches in the biosciences (Hoffmeyer 1997: 2; 
Laubichler 1999: 420; Barbieri 2003, 2008; Favareau 2010: 62-63; Gálik 2013: 860), such as ecology (Maran 2017), ethology (Delahaye 2019), molecular biology (Jerne 1985; Nossal 1987; Sercarz et al. 1988; Eder \& Rembold 1992; Faria 2008) and neurophysiology (Freeman 1998; Olds 2000; Cariani 2001; Freeman \& Rogers 2002). A comparison with earlier assessments of biosemiotics' actual role in the life sciences (Todt 1987: 425; Hoffmeyer 1997: 2; Kull 1999; Laubichler 1999: 420; Kull 2004; Schult 2004: 101) shows that the situation has hardly changed since the 1980s and 1990s. The acceptance of biosemiotic principles, albeit relatively limited, may be explained by the extreme amounts of biological data, the dynamics and the enormous number of interactions among living things and with their environment that make the limitations of the reductionist approach clear, and therefore necessitate the search for new approaches (Deppert 1992; Eder \& Rembold 1992).

A broader acceptance of biosemiotic principles in the biosciences can only be expected if it is clearly demonstrated how biosemiotics is able to offer new insights that are out of the reach or scope of other, more established disciplines and go beyond a mere description or reformulation of known facts in other, semiotic terms. In our paper we want to show that a biosemiotic approach is able to identify species-specific morphological characters in spiders that have gone unnoticed so far.

\section{Biosemiotics and Zoological Systematics: Overcoming Typology, Restrengthening Morphology}

Over the course of the twentieth century morphology has suffered a dramatic loss of significance within the biological sciences (Riedl 2006). In particular, morphological taxonomy is regarded by many as a dying discipline (Bik 2017). Already around 1900 the discovery of morphologically indistinguishable but reproductively isolated sibling or cryptic species on the one hand and on the other hand of highly distinct intrapopulational variants in one and the same species revealed that a merely morphological species concept was insufficient (Mayr 1992; 2000). Generally speaking, the dominant position previously held by the morphological species concept was taken over by the biological species concept, defining species as groups of interbreeding natural populations that are reproductively isolated from other such groups (Mayr 1940: 256, 1942: 256). However, we should bear in mind that there are more than 20 different species concepts (Mayden 1997; Lloyd 2001). In his defense of the biological species concept Mayr argued that the morphological species concept was typological. Mayr's equation of morphological and typological species, although heavily criticized by others (Wheeler and Platnick 2000; Knapp 2008), still reflects a common attitude. Also, Hennig, the founder of the influential phylogenetic species concept, argued against an uncritical use of similarity relationships and rejected a purely morphological definition of species, which he considered typological (Hennig 1966: 43-44, 78-80, 148, 239; Wiley and Mayden 2000).

Even if a purely morphological species concept is worthy of criticism, one must not forget that a recurrence to morphological characters can be helpful to identify reproductive communities. Within the biological species concept based on reproductive isolation, those morphological traits that are involved in pre-mating isolating mechanisms such as behavioral isolation and mechanical isolation have gained considerable 
weight (Mayr 1970: 57). Another species concept based on sexual reproduction is Paterson's recognition concept of species, where the members of a species share a common fertilization system, a subset of which is the Specific-Mate Recognition System (Paterson 1985, 1988; Masters et al. 1987; Lambert and Spencer 1995; Stamos 2003: 197-199; Mallet 2013: 682-683). Among the characters contributing to the recognition of an appropriate mating partner and the achievement of fertilization Paterson (1988: 69) mentions "coadapted signals and receivers of mating partners, and their coadapted organs of gamete delivery and reception". This reference to the signal function of characters, often morphological ones, shares a common perspective with biosemiotics (Favareau 2010; Kull 2016). Accordingly, Kull (2016) states that Paterson's "recognition concept of species is basically communicational and semiotic" and that the "biosemiotic conception of species largely stems from the work of Hugh Paterson", while its origins can be traced back as far as Peterson's (1903, 1905a, b) works on the origin of species by physiological isolation. Central to the biosemiotic species concept is the notion of an individual's recognition window. In biparental reproduction, the recognition window is responsible for dividing potential partners into compatible and incompatible ones. Thus, it is a decisive factor for producing species and holding them together.

To sum up, focusing on and identifying those morphological structures that are crucial for the recognition of potential reproductive partners, or essential for successful copulation, sperm transfer and fertilization, are a suitable means to free morphology from recurrent and well-trodden reproaches of being "typological". With our paper we would like to join the ranks of those who have already stressed the importance of biosemiotics for morphology in other contexts, such as mimicry and visual communication (Kleisner 2008a, b, 2015; Kleisner and Maran 2014; Brejcha and Kleisner 2016; Maran 2017; Kleisner and Saribay 2019).

\section{The Application of Semiotic Principles in Spider Taxonomy}

\section{Some General Remarks on Spider Taxonomy}

For practical reasons taxonomy in spiders mainly uses morphological characters. Its interest focuses on the genitalia, that is the male secondary copulatory organ (palpal bulb) and the female reproductive organs, as determining taxonomical relationships and phylogeny requires more than a superficial comparison of similarities between indiscriminately chosen traits. However, as we will see, it is often the case that when it comes to analyzing the structure of the spiders' reproductive organs authors are content with depicting and describing every detail without singling out those parts that are decisive for intraspecific communication processes. Thus, one might argue that while choosing the reproductive organs as basis for the establishment of spider taxonomy is clearly not typological, the way in which the reproductive organs are described is often "extremely typological" (Eberhard and Huber 2010: 255). In our view it is a dangerous oversimplification to state that, because "the bulb of a male spider fits only into the genital opening of a female of the same species, [...] the shape of all bulb components is species specific" (Quade et al. 2019). 
Male spiders do not have primary copulatory organs. Instead, the distal end of the last segment of the palpus (the second pair of appendages), the tarsus (cymbium), has been modified to transfer sperm. This genital appendage of the male's palpus, the socalled bulb, is more or less complicated in structure. The corresponding female copulation organ (vulva, epigyne) is also very diverse among different species. During copulation, the palpal organ of the male is partially inserted into the female's genital opening, which lies hidden in the epigyne's epigastric furrow and leads into the fertilization duct. The mutual morphological fit between the male and female structures is a prerequisite for successful sperm transfer (see also Foelix 2011: 226 sqq., Comstock 1910: 161 sqq.). The external sexual organs are often so specific among different species that they are used by systematists as an important feature in differentiating species. However, usually it is not taken into account that only very specific areas of the male's bulb are complementary to certain parts of the female's genital structure and have a communication function.

Publications referring to genital structures in spiders - to mention only a few, randomly selected studies (Engelhardt 1910; Gerhardt 1921; Gering 1953; Levy 1991; Uhl 2000; Burger \& Kropf 2007; Jäger \& Wunderlich 2012; Zakharov \& Ovtcharenko 2013; Jäger 2015) - usually contain highly detailed drawings of these structures. Yet only a few authors describe the interrelation between the genital structures of the two sexes at all. Sierwald (1984: 411) shows an embolus that got stuck in the vulva. Grasshoff $(1968,1973)$ gives a very detailed account of the genitalmorphological structures and their function in spiders of the subfamily Araneinae, based on his investigation of animals preserved in copula. Loerbroks (1984) examined structure and function of the male and female genitalia, including coupling mechanisms in Misumena vatia, Schult (1983) and Schult and Sellenschlo (1983) in N. clavipes and $N$. pilipes ssp. fenestrata. Loerbroks (1984: 397) even proposed a technical model of the coupling mechanism. Though very precise and complex, these investigations do not express the communicative and biosemiotic aspect, that is, they do not focus on the complementary areas of the bulb and the female genitalia. This is due to a quasitypological approach, whereas the application of biosemiotics involves different research methods and perspectives. That shows how theory impacts research findings.

Huber (1993) was the first to combine the method of freeze-fixation of spiders in copula and subsequent preparation of serial sections of the copulatory organs in functional contact. His numerous publications on genital mechanics and copulatory mechanisms mainly in Pholcids contain highly detailed morphological studies of the genital structures and their function (Huber 1994a, b, 1995a, b, 1997, 1998, 1999, 2002; Huber \& Eberhard 1997). Huber (1993) also raises the important question of whether the female can evaluate the mechanical fit of those structures of the male copulatory organ that come into contact. He concludes (Huber 1993: 2445) that "although receptors could not be found in the female's contact zones, tactile stimulation cannot be definitely excluded. There might be undiscovered internal receptors in the membraneous parts of the epigastric furrow and the genital pouches." With his concept of "contact zones" and his idea that the genital structures' coming into contact might be perceived by the female (and thus function as a sign for the female, one might add) Huber's approach has a lot in common with a biosemiotic point of view. Furthermore, he (Huber 2002: 105) remarks that the ,taxonomic literature provides a wealth of illustrations, mainly of the genitalia" and that these "simple drawings are usually 
sufficient for species identification, but rarely provide any detail." And it is precisely these details that can be decisive for species recognition. Elsewhere, Eberhardt and Huber (Eberhard \& Huber 2010: 255) use the term "cooperative structures", which connotes communication processes. Huber's studies certainly contain biosemiotic principles, without explicitly mentioning this term.

\section{The Spider Species Nephila clavipes and Nephila pilipes ssp. fenestrata as Case Studies}

Several studies of the functional morphology of spider genitalia have shown that genital coupling in spiders involves very complex interactions between the male and female genital structures (Grasshoff 1968, 1973; Huber 1993, 1994a, b, 1998; Uhl et al. 1995, 2007). From a biosemiotic point of view not only mate recognition constitutes a communication process, but also the fitting between coadapted male and female genital structures can be regarded as a sign whose interpretation leads to certain effects, such as sperm transfer. Using two species of the spider genus Nephila as an example, in what follows we will show that a biosemiotic approach opens new perspectives on how to assess the taxonomic value of morphological characters.

As early as 1960 Hermann Wiehle provided a fundamental, but unfortunately littlenoticed contribution about the embolus of the male bulb and functional correlates between structures of the bulb and of the epigyne resp. vulva (Wiehle 1960) in a large number of spider species. Certainly, his emphasis that all considerations about the form of the embolus take into account the construction of the corresponding vulva in order to enable explanations through this correlation (Wiehle 1960: 480) was a step in the right direction. Nevertheless, Wiehle's illustration (1967: 195, Fig. 47) of the bulb and embolus of " $N$. madagascariensis" omits essential species-relevant features. Moreover, his depiction of the pedipalp seems to have been falsely assigned to N. madagascariensis. Although the drawing is very imprecise, a comparison with drawings of the bulb of $N$. clavipes (Pickard-Cambridge 1901: Pl. VII; Levi 1980: 19, 21; Heimer 1982: 46; Schult \& Sellenschlo 1983: 223; Levi \& Eickstedt 1989: 51; Hormiga et al. 1995: 332) and of the bulb of N. madagascariensis (Saaristo 1978: 120; Saaristo 2010: 95) by other authors suggests that this is not the bulb of $N$. madagascariensis, but of $N$. clavipes. Wiehle's error may be due to the fact that the tip of the embolus was not the focus of his investigations. Unfortunately, the remaining literature on Nephila species (Karsch 1879: 838; Gerhardt 1933; Archer 1958; Heimer 1982; Schult 1983; Liao et al. 1984: 68; Clausen 1987; Barrion et al. 1988; Higgins 1989: 749; Reiche 1992: 12; Uhl \& Vollrath 1998: 45; Schneider et al. 2001; Ramos et al. 2005: 1993; Fromhage \& Schneider 2006; Kim 2006: 208; Harvey et al. 2007: 422; Kuntner \& Coddington 2009; Kuntner et al. 2009a, 2009b) also fails to provide sufficiently detailed information on the shape and function of the embolus.

Figure 1a (N. clavipes) from Schult and Sellenschlo (1983) does not show in sufficient detail the apical area of the bulb (encircled), that is the embolus, which is of interest here. The same applies to Fig. 1c from Wiehle (1967: 195, Fig. 47). In none of these figures is the function of the embolus clearly shown. Moreover, the corresponding female part was completely omitted. Figure $1 \mathrm{~d}$ shows a hypothetical interaction of the complementary elements of the female's epigyne and the male's bulb. The tip of the bulb's embolus (Et) is surrounded 


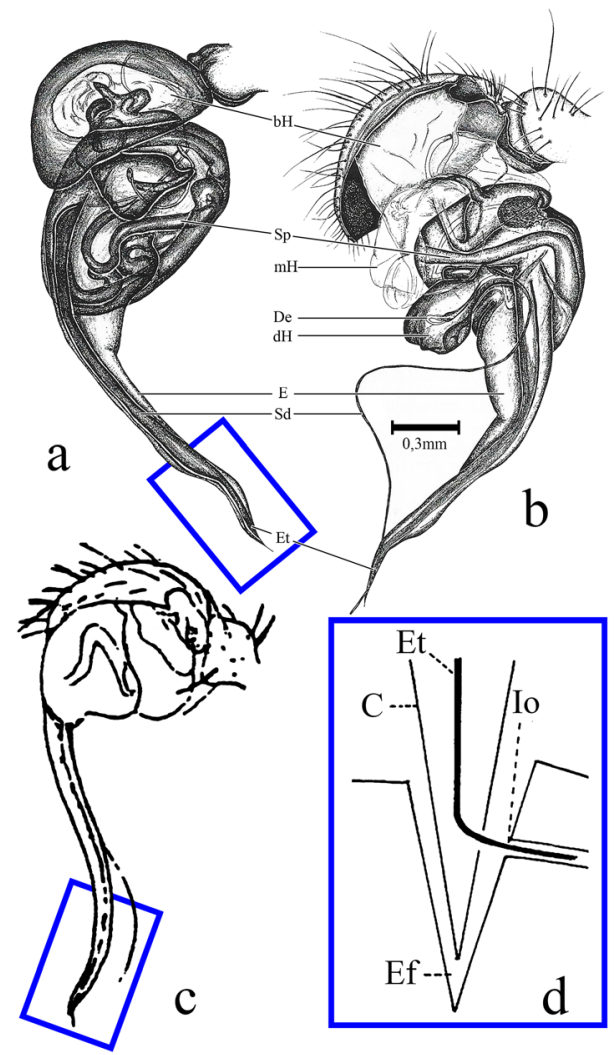

Fig. 1 Nephila clavipes. a bulb, unexpanded state (left) and b expanded state (right), rectangle indicates tip of the bulb, $D e=$ ductus ejaculatorius, $E=$ embolus, $E t=$ embolus's tip, $b H / m H / d H=$ basal, median, distal hematodocha, $C=$ conductor, $S p=$ spermophor, $S d=$ distal part of the spermophor, c right pedipalp from lateral (falsely attributed to Nephila madagascariensis by Wiehle (1967)), "the embolus jumped out of its guidance" (Wiehle 1967: 195, translated); rectangle indicates tip of the bulb, d rectangle indicates morphological zone of an intraspecific communication and sign-interpreting process, conductor $(C)$ lying in the epigastric furrow $(E f)$, embolus's tip $(E t)$ inserted into the introductory opening $(I o)$ of the vulva (schematic representation). a, b, d taken from Schult and Sellenschlo (1983), c taken from Wiehle (1967)

by the conductor $(\mathrm{C})$ that lies in the epigastric furrow (Ef) of the female's epigyne. As the bulb's conductor is no closed tube, but laterally open, with increasing hemolymphic pressure it takes on the shape of a channel, so that the flagelliform tip of the embolus is no longer completely enveloped. Finally, the embolus's tip exits the conductor sideways and is inserted into the introductory opening (Io) of the vulva (Schult and Sellenschlo 1983). In N. pilipes ssp. fenestrata (Fig. 2) the situation is different from $N$. clavipes in that the conductor containing the embolus possesses a discrete terminal exit opening. Furthermore, the conductor's tip is bent, having the shape of a hook, and fits exactly into the pouch-like entrance area of the vulva's introductory duct (Fig. 2d) (Schult and Sellenschlo 1983)

From a biosemiotic point of view these mechanical descriptions are no sufficient analysis, as they do not take into consideration the communicational and 


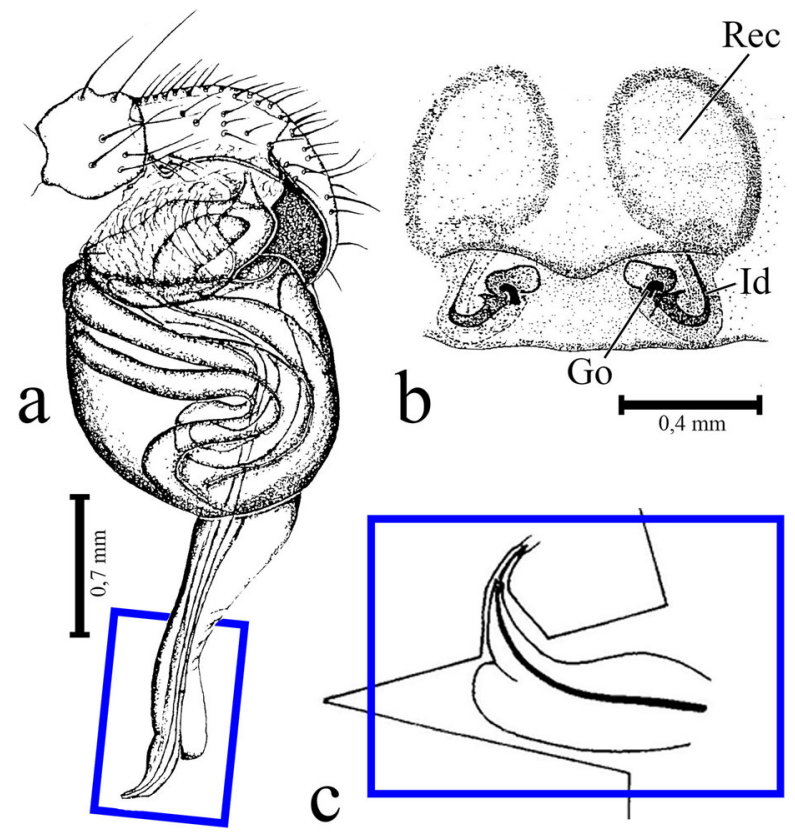

Fig. 2 Nephila pilipes ssp. fenestrata. a bulb, rectangle indicates tip of the bulb, b vulva (dorsal view), Go genital opening, Id introductory duct, Rec receptaculum seminis, c fitting of the bulb's tip into the pouch-like entrance area of the vulva's introductory duct (schematic representation), a-c taken from Schult and Sellenschlo (1983)

functional aspects of the whole process. It is reasonable to assume that the initiation of sperm transfer starts when the exit opening of the male embolus's ejaculatory duct has reached its optimal position by coming into contact with the opening of the female fertilization duct. The achievement of such an optimal position of the embolus can be considered a sign and sperm transfer its interpretation. We hypothesize that certain morphological details hitherto unnoticed in the embolus ensure that among the many possible ones only a specific position of the embolus causes sperm transfer. Only future scanning electron-microscopical and CT examinations can confirm or refute our hypothesis. But it should be mentioned that there are some indications from studies on other spider species that our assumption may be right. In Argiope bruennichi, judging by the shape of the sperm transferring part (e1 in Fig. 4D in Uhl et al. 2007) of the embolus, it seems that the correct position of the embolus and the exit opening of its ejaculatory duct is achieved when the embolus's sperm-transferring part lies completely against the inner wall of the atrium, an aspect that until now has not received the attention it deserves. Furthermore, first scanning electron microscope (SEM) photographs of the emboli of Segestria florentina and Segestria bavarica by two authors of this paper have revealed a conspicuous, hitherto undocumented spur-like structure at some distance from the embolus's opening (not yet published). Generally, detailed investigations of the morphological structure of the embolus are extremely rare. 


\section{Conclusion}

As exemplified by two different Nephila species, from a biosemiotic point of view the microstructures of the male bulb's embolus and the corresponding female epigynal and vulval parts form the morphological zone of an intraspecific communication and signinterpreting process that is one of the prerequisites for sperm transfer. Hence these morphological elements deserve peculiar attention. They are of high taxonomic value, as they play an essential role in mating and fertilization and consequently in establishing and preserving a reproductive community. As is well known, in addition to morphological structures there are a number of other factors, such as behaviour (Schneider \& Andrade 2011), pheromones (Gaskett 2007), habitat, courtship periods etc., that either prevent mating between species or enhance specific mate recognition and the achievement of fertilization. Therefore, even with compatible morphological structures, a reproductive community cannot be assumed for sure. However, if a match fails between structures that are necessary for communication processes involved in the recognition of an appropriate mating partner and the achievement of fertilization, reproductive isolation follows per definitionem. In our view a biosemiotic approach clearly helps to identify those relevant structures. Especially when behavioural or physiological traits are unavailable decision processes would benefit from a biosemiotics-based species delimitation approach as a new source of data within the multidisciplinary undertaking of modern integrative taxonomy (Dayrat 2005; Řezác et al. 2014). Thus, biosemiotics contributes to restrengthening morphology and to counteracting its severe decline that has started in the twentieth century.

Acknowledgements This study was supported by a grant from the University of Hamburg. We are most grateful to Dr. A. Röper-Steinhauer (Leuphana University Lüneburg) and Dr. W. Hinners for carefully reading a previous draft and checking the content and language. Our thanks also go to Dr. Philipp Schult (University of Bonn) for helping us with image processing. Finally, we would like to thank Prof. Dr. Lisa Kirch for proofreading the final manuscript.

Funding Open Access funding enabled and organized by Projekt DEAL.

Open Access This article is licensed under a Creative Commons Attribution 4.0 International License, which permits use, sharing, adaptation, distribution and reproduction in any medium or format, as long as you give appropriate credit to the original author(s) and the source, provide a link to the Creative Commons licence, and indicate if changes were made. The images or other third party material in this article are included in the article's Creative Commons licence, unless indicated otherwise in a credit line to the material. If material is not included in the article's Creative Commons licence and your intended use is not permitted by statutory regulation or exceeds the permitted use, you will need to obtain permission directly from the copyright holder. To view a copy of this licence, visit http://creativecommons.org/licenses/by/4.0/.

\section{References}

Archer, A. F. (1958). Studies in the orbweaving spiders (Argiopidae). 4. American Museum Novitates, 1922, $1-21$.

Barbieri, M. (2003). The organic codes. An introduction to semantic biology. Cambridge: Cambridge University Press.

Barbieri, M. (2008). Biosemiotics: A new understanding of life. Naturwissenschaften, 95(7), 577-599. 
Barrion, A. A., Casal, C. V., Taylo, L. D., \& Amalin, D. M. (1988). Two orb-weaving spiders (Araneae: Araneidae) in the Philippines causing araneidism. Philippine Journal of Science, 116, 245-254.

Bik, H. M. (2017). Let's rise up to unite taxonomy and technology. PLoS Biology, 15(8), e2002231. https:// doi.org/10.1371/journal.pbio.2002231.

Brejcha, J., \& Kleisner, K. (2016). Turtles are not just walking stones: Conspicuous coloration and sexual selection in freshwater turtles. Biosemiotics, 9(2), 247-266.

Burger, M., \& Kropf, C. (2007). Genital morphology of the haplogyne spider Harpactea lepida (Arachnida, Araneae, Dysderidae). Zoomorphology, 126, 45-52.

Cariani, P. (2001). Symbols and dynamics in the brain. BioSystems, 60, 59-83.

Clausen, I. H. S. (1987). On the biology and behaviour of Nephila senegalensis senegalensis (Walckenaer, 1837). Bulletin of the British Arachnological Society, 7, 147-150.

Comstock, J. H. (1910). The palpi of male spiders. Annals of the Entomological Society of America, 3(3), 161185.

Dayrat, B. (2005). Towards integrative taxonomy. Biological Journal of the Linnean Society, 85, 407-415.

Delahaye, P. (2019). A semiotic methodology for animal studies. Cham: Springer.

Deppert, W. (1992). Das Reduktionismusproblem und seine Überwindung. In W. Deppert, H. Kliemt, B. Lohff, \& J. Schaefer (Eds.), Wissenschaftstheorien in der Medizin (pp. 275-323). Berlin: de Gruyter.

Eberhard, W. G., \& Huber, B. A. (2010). Spider genitalia. Precise maneuvers with a numb structure in a complex lock. In J. L. Leonard \& A. Córdoba-Aguilar (Eds.), The evolution of primary sexual characters in animals (pp. 249-284). New York: Oxford University Press.

Eder, J., \& Rembold, H. (1992). Biosemiotics - A paradigm of biology. Biological signalling on the verge of deterministic chaos. Naturwissenschaften, 79, 60-67.

Faria, M. (2008). RNA as code makers: A biosemiotic view of RNAi and cell immunity. In M. Barbieri (Ed.), Introduction to biosemiotics. The new biological synthesis (pp. 347-364). Dordrecht: Springer.

Favareau, D. (2010). Essential readings in biosemiotics. Anthology and commentary. Dordrecht: Springer.

Foelix, R. F. (2011). Biology of spiders (3rd ed.). Oxford: Oxford University Press.

Freeman, W. J. (1998). A watershed in the study of nonlinear neural dynamics. In E. Basar (Ed.), Dynamics of sensory and cognitive processing by the brain (pp. 378-381). Berlin: Springer.

Freeman, W. J., \& Rogers, L. J. (2002). Fine temporal resolution of analytic phase reveals episodic synchronization by state transitions in gamma EEGs. Journal of Neurophysiology, 87(2), 937-945.

Fromhage, L., \& Schneider, J. M. (2006). Emasculation to plug up females: The significance of pedipalp damage in Nephila fenestrata. Behavioral Ecology, 17, 353-357.

Gálik, D. (2013). Biosemiotics: A new science of biology? FILOZOFIA, 68(10), 859-867.

Gaskett, A. C. (2007). Spider sex pheromones: Emission, reception, structures, and functions. Biological Reviews, 82, 27-48.

Gérard, B. (2014). Information and life. Dordrecht: Springer.

Gerhardt, U. (1921). Vergleichende Studien über die Morphologie des männlichen Tasters und die Biologie der Kopulation der Spinnen. Archiv für Naturgeschichte, 87A(4), 78-247.

Gerhardt, U. (1933). Neue Untersuchungen zur Sexualbiologie der Spinnen, insbesondere an Arten der Mittelmeerländer und der Tropen. Zeitschrift für Morphologie und Ökologie der Tiere, 27(1), 1-75.

Gering, R. L. (1953). Structure and function of the genitalia in some American Agelenid spiders. Smithsonian Miscellaneous Collections, 121(4), 1-84.

Ghiselin, M. T. (2003). Preface. In M. Barbieri (Ed.), The organic codes: An introduction to semantic biology (pp. ix-xii). Cambridge: Cambridge University Press.

Grasshoff, M. (1968). Morphologische Kriterien als Ausdruck von Artgrenzen bei Radnetzspinnen der Subfamilie Araneinae (Arachnida: Araneae: Araneidae). Abhandlungen der Senckenbergischen Naturforschenden Gesellschaft, 516, 1-100.

Grasshoff, M. (1973). Bau und Mechanik der Kopulationsorgane der Radnetzspinne Mangora acalypha (Arachnida, Araneae). Zeitschrift für Morphologie der Tiere, 74(3), 241-251.

Harvey, M. S., Austin, A. D., \& Adams, M. (2007). The systematics and biology of the spider genus Nephila (Araneae: Nephilidae) in the Australasian region. Invertebrate Systematics, 21, 407-451.

Heimer, S. (1982). Interne Arretierungsmechanismen an den Kopulationsorganen männlicher Spinnen (Arachnida, Araneae). Ein Beitrag zur Phylogenie der Araneoidea. Entomologische Abhandlungen, Staatliches Museum für Tierkunde Dresden, 45, 35-64.

Hennig, W. (1966). Phylogenetic systematics. London: University of Illinois Press.

Higgins, L. E. (1989). Effect of insemination on the morphology of the internal female genitalia of the spider Nephila clavipes (Araneae: Araneidae). Annals of the Entomological Society of America, 82(6), 748-753.

Hoffmeyer, J. (1997). Biosemiotics: Towards a new synthesis in biology. European Journal for Semiotic Studies, 9(2), 355-376. 
Hormiga, G., Eberhard, W. G., \& Coddington, J. A. (1995). Web-construction behaviour in Australian Phonognatha and the phylogeny of nephiline and tetragnathid spiders (Araneae: Tetragnathidae). Australian Journal of Zoology, 43, 313-364.

Huber, B. A. (1993). Genital mechanics and sexual selection in the spider Nesticus cellulanus (Araneae: Nesticidae). Canadian Journal of Zoology, 71, 2437-2447.

Huber, B. A. (1994a). Genital morphology, copulatory mechanism and reproductive biology in Psilochorus simoni (Berland, 1911) (Pholcidae; Araneae). Netherlands Journal of Zoology, 44(1-2), 85-99.

Huber, B. A. (1994b). Copulatory mechanics in the funnel-web spiders Histopona torpida and Textrix denticulata (Agelenidae, Araneae). Acta Zoologica (Stockholm), 75(4), 379-384.

Huber, B. A. (1995a). Copulatory mechanism in Holocnemus pluchei and Pholcus opilionoides, with notes on male cheliceral apophyses and stridulatory organs in Pholcidae (Araneae). Acta Zoologica (Stockholm), 76(4), 291-300.

Huber, B. A. (1995b). Genital morphology and copulatory mechanics in Anyphaena accentuate (Anyphaenidae) and Clubiona pallidula (Clubionidae: Araneae). Journal of Zoology, London, 235, 689-702.

Huber, B. A. (1997). On American 'Micromerys' and Metagonia (Araneae, Pholcidae), with notes on natural history and genital mechanics. Zoologica Scripta, 25(4), 341-363.

Huber, B. A. (1998). Genital mechanics in some neotropical pholcid spiders (Araneae: Pholcidae), with implications for systematics. Journal of Zoology, London, 244, 587-599.

Huber, B. A. (1999). Sexual selection in pholcid spiders (Araneae, Pholcidae): Artful chelicerae and forceful genitalia. The Journal of Arachnology, 27, 135-141.

Huber, B. A. (2002). Functional morphology of the genitalia in the spider Spermophora senoculata (Pholcidae, Araneae). Zoologische Anzeiger, 241, 105-116.

Huber, B. A., \& Eberhard, W. G. (1997). Courtship, copulation, and genital mechanics in Physocyclus globosus (Araneae, Pholcidae). Canadian Journal of Zoology, 74, 905-918.

Jäger, P. (2015). Conductor-less and vertically niched: New species of the genus Pseudopoda (Araneae: Sparassidae: Heteropodinae) from Myanmar. Arachnology, 16(9), 333-350.

Jäger, P., \& Wunderlich, J. (2012). Seven new species of the spider genus Otacilia Thorell 1897 (Araneae: Corinnidae) from China, Laos and Thailand. Beiträge zur Araneologie, 7, 251-271.

Jerne, N. K. (1985). The generative grammar of the immune system. Bioscience Reports, 5, 439-451.

Karsch, F. (1879). Die Zwerg-Männchen der Araneiden-Gattungen: Nephila, Celaenia und Caerostris. Zeitschrift für die Gesammten Naturwissenschaften, 52, 838-842.

Kim, J.-P. (2006). Redescription of Nephila maculata (Fabricius), 1793 from Cambodia (Araneae, Nephilidae). Korean Arachnology, 22, 203-209.

Kleisner, K. (2008a). Homosemiosis, mimicry and superficial similarity: Notes on the conceptualization of independent emergence of similarity in biology. Theory in Biosciences, 127(1), 15-21.

Kleisner, K. (2008b). The semantic morphology of Adolf Portmann: A starting point for the biosemiotics of organic form? Biosemiotics, 1(2), 207-219.

Kleisner, K. (2015). Semantic organs: The concept and its theoretical ramifications. Biosemiotics, 8(3), 367379.

Kleisner, K., \& Maran, T. (2014). Visual communication in animals: Applying Portmannian and Uexküllian biosemiotic approach. In D. Machin (Ed.), Visual communication (pp. 659-676). Berlin: De Gruyter.

Kleisner, K., \& Saribay, S. A. (2019). The dual nature of mimicry: Organismal form and beholder's eye. Biosemiotics, 12(1), 79-98.

Knapp, S. (2008). A century of evolution: Ernst Mayr (1904-2005). Species concepts and floras: what are species for? Biological Journal of the Linnean Society, 95, 17-25.

Kull, K. (1999). Biosemiotics in the twentieth century: A view from Biology. Semiotica, 127(1/4), 385-414.

Kull, K. (2004). The semiotic turn in biology. In J. Schult (Ed.), Biosemiotik - praktische Anwendung und Konsequenzen für die Einzeldisziplinen (Studien zur Theorie der Biologie, vol. 6) (pp. 27-34). Berlin: VWB.

Kull, K. (2016). The biosemiotic concept of the species. Biosemiotics, 9, 61-71.

Kuntner, M., \& Coddington, J. A. (2009). Discovery of the largest orbweaving spider species: the evolution of gigantism in Nephila. PLoS One, 4(10), e7516. https://doi.org/10.1371/journal.pone.0007516.

Kuntner, M., Kralj-Fišer, S., Schneider, J. M., \& Li, D. (2009a). Mate plugging via genital mutilation in nephilid spiders: an evolutionary hypothesis. Journal of Zoology, London, 277, 257-266.

Kuntner, M., Coddington, J. A., \& Schneider, J. M. (2009b). Intersexual arms race? Genital coevolution in nephilid spiders (Araneae, Nephilidae). Evolution, 63, 1451-1463.

Lambert, D. M., \& Spencer, H. G. (Eds.). (1995). Speciation and the recognition concept: theory and application. Baltimore: Johns Hopkins University Press. 
Laubichler, M. D. (1999). A semiotic perspective on biological objects and biological functions. Semiotica, $127(1 / 4$ special issue), 415-431.

Levi, H. W. (1980). The orb-weaver genus Mecynogea, the subfamily Metinae and the genera Pachygnatha, Glenognatha and Azilia of the subfamily Tetragnathinae north of Mexico (Araneae: Araneidae). Bulletin of the Museum of Comparative Zoology, 149(1), 1-74.

Levi, H. W., \& von Eickstedt, V. R. D. (1989). The Nephilinae spiders of the neotropics. Memórias do Instituto Butantan, 51, 43-56.

Levy, G. (1991). On some new and uncommon spiders from Israel (Araneae). Bulletin of the British Arachnological Society, 8, 227-232.

Liao, C. H., Chen, M. G., \& Song, D. X. (1984). On morphological characteristics and biology of the silk spider Nephila imperialis (Araneae: Araneidae). Acta Zoologica Sinica, 30, 67-71.

Lloyd, J. E. (2001). On research and entomological education V: A species (c)oncept for fireflyers, at the bench and in old fields, and back to the Wisconsian Glacier. The Florida Entomologist, 84(4), 587-601.

Loerbroks, A. (1984). Mechanik der Kopulationsorgane von Misumena vatia (Clerck, 1757) (Arachnida: Araneae: Thomisidae). Verhandlungen des Naturwissenschaftlichen Vereins in Hamburg, 27, 383-403.

Mallet, J. (2013). Species, concepts of. In S. A. Levin (Ed.), Encyclopedia of Biodiversity (Vol. 6, pp. 679691). Oxford: Elsevier.

Maran, T. (2017). Mimicry and meaning: Structure and semiotics of biological mimicry. Cham: Springer.

Masters, J. C., Rayner, R. J., McKay, I. J., Potts, A. D., Nails, D., Ferguson, J. W., et al. (1987). The concept of species: recognition versus isolation. South African Journal of Science, 83, 534-537.

Mayden, R. L. (1997). A hierarchy of species concepts: The denouement in the saga of the species problem. In M. F. Claridge, H. A. Dawah, \& M. R. Wilson (Eds.), Species: The units of biodiversity (pp. 381-424). New York: Chapman \& Hall.

Mayr, E. (1940). Speciation phenomena in birds. The American Naturalist, 74, 249-278.

Mayr, E. (1942). Systematics and the origin of species. New York: Columbia Univ. Press.

Mayr, E. (1970). Populations, species, and evolution: an abridgment of animal species and evolution. Cambridge: Belknap Press of Harvard University Press.

Mayr, E. (1992). Local flora and the biological species concept. American Journal of Botany, 79(2), 222-238.

Mayr, E. (2000). The biological species concept. In Q. D. Wheeler \& R. Meier (Eds.), Species concepts and phylogenetic theory: A debate (pp. 17-29). New York: Columbia University Press.

Nossal, G. J. V. (1987). Experimentally induced and naturally acquired immunologic tolerance: Key issues for B Lymphocyte research. In E. E. Sercarz \& J. A. Berzofsky (Eds.), Immunogenecity of protein antigens: Repertoire and regulation (Vol. II, pp. 13-18). Boca Raton: CRC Press.

Olds, D. D. (2000). A Semiotic Model of Mind. Journal of the American Psychoanalytic Association, 48(2), 497-529.

Paterson, H. (1985). The recognition concept of species. In E. S. Vrba (Ed.), Species and speciation (pp. 2129). Pretoria: Transvaal Museum.

Paterson, H. (1988). On defining species in terms of sterility: problems and alternatives. Pacific Science, 42 , $65-71$.

Pattee, H. H. (1995). Evolving self-reference: Matter, symbols, and semantic closure. Communication and Cognition - Artificial Intelligence, 12(1-2), 9-27.

Petersen, W. (1903). Entstehung der Arten durch physiologische Isolierung. Biologisches Centralblatt, 23, $468-477$.

Petersen, W. (1905a). Über die Bedeutung der Generationsorgane für die Entstehung der Arten. In M. Bedot (Ed.), Compte-rendu des séances du sixième Congrès international de zoologie, tenu à Berne du 14 au 16 août 1904 (pp. 213-224). Genève: Imprimerie W. Kündig \& Fils.

Petersen, W. (1905b). Über beginnende Art-Divergenz (Hadena adusta Esp. - Lepidopt.). Archiv für Rassenund Gesellschaftsbiologie, 2, 641-662.

Pickard-Cambridge, F. O. (1901). On a collection of spiders from the Bahama Islands made by J. L. Bonhote, Esq.; with characters of a new genus and species of Mygalomorphae. Annals and Magazine of Natural History, 7 - seventh series, 322-332.

Quade, F. S. C., Holtzheimer, J., Frohn, J., Töpperwien, M., Salditt, T., \& Prpic, N.-M. (2019). Formation and development of the male copulatory organ in the spider Parasteatoda tepidariorum involves a metamorphosis-like process. Scientific Reports, 9. https://doi.org/10.1038/s41598-019-43192-9.

Ramos, M., Coddington, J. A., Christenson, T. E., \& Irschick, D. J. (2005). Have male and female genitalia coevolved? A phylogenetic analysis of genitalic morphology and sexual size dimorphism in web-building spiders (Araneae: Araneoidea). Evolution, 59, 1989-1999.

Reiche, W. (1992). Beitrag zur Ethologie von Nephila senegalensis (Walckenaer) (Arachnida: Aranea [sic]: Araneidae). Arachnologischer Anzeiger, 3(10), 10-13. 
Řezáč, M., Gasparo, F., Král, J., \& Heneberg, P. (2014). Integrative taxonomy and evolutionary history of a newly revealed spider Dysdera ninnii complex (Araneae: Dysderidae). Zoological Journal of the Linnean Society, 172, 451-474.

Riedl, R. (2006). Der Verlust der Morphologie. Wien: Seifert.

Saaristo, M. I. (1978). Spiders (Arachnida, Araneae) from the Seychelle Islands, with notes on taxonomy. Annales Zoologici Fennici, 15, 99-126.

Saaristo, M. I. (2010). Araneae. In J. Gerlach \& Y. M. Marusik (Eds.), Arachnida and Myriapoda of the Seychelles islands (pp. 8-306). Manchester: Siri Scientific Press.

Schneider, J., \& Andrade, M. (2011). Mating behaviour and sexual selection. In M. E. Herberstein (Ed.), Spider behaviour: flexibility and versatility (pp. 215-274). Cambridge: Cambridge Univ. Press.

Schneider, J. M., Thomas, M. L., \& Elgar, M. A. (2001). Ectomised conductors in the golden orb-web spider, Nephila plumipes (Araneoidea): a male adaptation to sexual conflict? Behavioral Ecology and Sociobiology, 49, 410-415.

Schult, J. (1983). Simple bulbs in male spiders - primitive or derived? Verhandlungen des Naturwissenschaftlichen Vereins in Hamburg, 26, 155-160.

Schult, J. (2004). Morphologische Merkmale als Zeichen. In J. Schult (Ed.), Biosemiotik - praktische Anwendung und Konsequenzen für die Einzeldisziplinen (Studien zur Theorie der Biologie, vol. 6) (pp. 101-121). Berlin: VWB.

Schult, J., \& Sellenschlo, U. (1983). Morphologie und Funktion der Genitalstrukturen bei Nephila (Arach., Aran., Araneidae). Mitteilungen aus dem Hamburgischen Zoologischen Museum und Institut, 80, 221230.

Sercarz, E. E., Celada, F., Mitchison, N. A., \& Tada, T. (Eds.). (1988). The semiotics of cellular communication in the immune system. Berlin: Springer.

Sierwald, P. (1984). Madagassische Arten der Gattung Thalassius Simon, 1885 (Arachnida: Araneae: Pisauridae). Verhandlungen des Naturwissenschaftlichen Vereins in Hamburg (NF), 27, 405-416.

Stamos, D. N. (2003). The species problem. Biological species, ontology, and the metaphysics of Biology. Oxford: Lexington Books.

Todt, D. (1987). Nachrichten der DGS, Bereich Zoologie. Zeitschrift für Semiotik, 9(3-4), 425.

Uhl, G. (2000). Two distinctly different sperm storage organs in female Dysdera erythrina (Araneae: Dysderidae). Arthropod Structure \& Development, 29, 163-169.

Uhl, G., \& Vollrath, F. (1998). Genital morphology of Nephila edulis: implications for sperm competition in spiders. Canadian Journal of Zoology, 76, 39-47.

Uhl, G., Huber, B. A., \& Rose, W. (1995). Male pedipalp morphology and copulatory mechanism in Pholcus phalangioides (Fuesslin, 1775) (Araneae, Pholcidae). Bulletin of the British Arachnological Society, 10(1), 1-9.

Uhl, G., Nessler, S. H., \& Schneider, J. (2007). Copulatory mechanism in a sexually cannibalistic spider with genital mutilation (Araneae: Araneidae: Argiope bruennichi). Zoology, 110, 398-408.

von Engelhardt, V. (1910). Beiträge zur Kenntnis der weiblichen Copulationsorgane einiger Spinnen. Zeitschrift für Wissenschaftliche Zoologie, 96, 32-117.

Wheeler, Q. D., \& Platnick, N. I. (2000). A critique from the Wheeler and Platnick phylogenetic species concept perspective: Problems with alternative concepts of species. In Q. D. Wheeler \& R. Meier (Eds.), Species concepts and phylogenetic theory: A debate (pp. 133-145). New York: Columbia University Press.

Wiehle, H. (1960). Der Embolus des männlichen Spinnentasters. Verhandlungen der Deutschen Zoologischen Gesellschaft, 1960, 457-480.

Wiehle, H. (1967). Meta, - eine semientelegyne Gattung der Araneae (Arach.). Senckenbergiana biologica, 48(3), 183-196.

Wiley, E. O., \& Mayden, R. L. (2000). A defense of the evolutionary species concept. In Q. D. Wheeler \& R. Meier (Eds.), Species concepts and phylogenetic theory: A debate (pp. 198-208). New York: Columbia University Press.

Zakharov, B. P., \& Ovtcharenko, V. I. (2013). Structure of genital organs and mating process of the spider Hemicloea sundevalli Thorell, 1870 (Araneae: Gnaphosidae). Entomologica Americana, 119(3-4), 4756.

Publisher's Note Springer Nature remains neutral with regard to jurisdictional claims in published maps and institutional affiliations. 